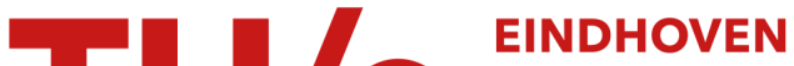 UNIVERSITY OF TECHNOLOGY
}

\section{Experimental demonstration of a new model-based SCR control strategy for cleaner heavy-duty diesel engines}

Citation for published version (APA):

Willems, F. P. T., \& Cloudt, R. P. M. (2011). Experimental demonstration of a new model-based SCR control strategy for cleaner heavy-duty diesel engines. IEEE Transactions on Control Systems Technology, 19(5), 13051313. https://doi.org/10.1109/TCST.2010.2057510

DOI:

10.1109/TCST.2010.2057510

Document status and date:

Published: 01/01/2011

\section{Document Version:}

Publisher's PDF, also known as Version of Record (includes final page, issue and volume numbers)

\section{Please check the document version of this publication:}

- A submitted manuscript is the version of the article upon submission and before peer-review. There can be important differences between the submitted version and the official published version of record. People interested in the research are advised to contact the author for the final version of the publication, or visit the $\mathrm{DOI}$ to the publisher's website.

- The final author version and the galley proof are versions of the publication after peer review.

- The final published version features the final layout of the paper including the volume, issue and page numbers.

Link to publication

\section{General rights}

Copyright and moral rights for the publications made accessible in the public portal are retained by the authors and/or other copyright owners and it is a condition of accessing publications that users recognise and abide by the legal requirements associated with these rights.

- Users may download and print one copy of any publication from the public portal for the purpose of private study or research.

- You may not further distribute the material or use it for any profit-making activity or commercial gain

- You may freely distribute the URL identifying the publication in the public portal.

If the publication is distributed under the terms of Article 25fa of the Dutch Copyright Act, indicated by the "Taverne" license above, please follow below link for the End User Agreement:

www.tue.nl/taverne

Take down policy

If you believe that this document breaches copyright please contact us at:

openaccess@tue.nl

providing details and we will investigate your claim. 


\title{
Experimental Demonstration of a New Model-Based SCR Control Strategy for Cleaner Heavy-Duty Diesel Engines
}

\author{
Frank Willems and Robert Cloudt
}

\begin{abstract}
Selective catalytic reduction (SCR) is a promising diesel aftertreatment technology that enables low nitrogen oxides $\left(\mathrm{NO}_{\mathrm{x}}\right)$ tailpipe emissions with relatively low fuel consumption. Future emission legislation is pushing the boundaries for SCR control systems to achieve high $\mathrm{NO}_{x}$ conversion within a tailpipe ammonia $\left(\mathrm{NH}_{3}\right)$ slip constraint, and to provide robustness to meet in-use compliance requirements. This work presents a new adaptive control strategy that uses an ammonia feedback sensor and an online ammonia storage model. Experimental validation on a 12-liter heavy-duty diesel engine with a 34-liter Zeolite SCR catalyst shows good performance and robustness against urea under- and over-dosage for both the European steady-state and transient test cycles. The new strategy is compared with a $\mathrm{NO}_{\mathrm{x}}$ sensor-based control strategy with cross-sensitivity compensation. It proved to be superior in terms of transient adaptation and taking an $\mathrm{NH}_{3}$ slip constraint into account.
\end{abstract}

Index Terms-Adaptive control, diesel engines, emission control, model-based control, robustness.

\section{NOMENCLATURE}

\section{Abbreviations and subscripts}

$\begin{array}{ll}\text { a } & \text { Ambient. } \\ \text { ads } & \text { Ammonia adsorption. } \\ \text { des } & \text { Ammonia desorption. } \\ \text { exh } & \text { Exhaust gas. } \\ \text { fa } & \text { Fast [in SCR reaction (4)]. } \\ \text { g } & \text { Gas phase. } \\ \text { oxno } & \text { Ammonia oxidation [in SCR reaction (6)]. } \\ \text { oxn2 } & \text { Ammonia oxidation [in SCR reaction (7)]. } \\ \text { ref } & \text { Reference. } \\ \text { s } & \text { Substrate catalyst. } \\ \text { sl } & \text { Slow [in SCR reaction (5)]. } \\ \text { st } & \text { Standard [in SCR reaction (3)]. }\end{array}$

Manuscript received March 06, 2009; revised September 20, 2009 and February 02, 2010; accepted April 15, 2010. Manuscript received in final form July 05, 2010. Date of publication September 07, 2010; date of current version August 17, 2011. Recommended by Associate Editor U. Christen. This work was supported in part by the Dutch Ministry of Economical Affairs.

F. Willems is with the Department of Mechanical Engineering, Eindhoven University of Technology, $5600 \mathrm{MB}$ Eindhoven, The Netherlands, and also with the Powertrains Department, TNO Automotive, 5700 AT Helmond, The Netherlands (e-mail: f.p.t.willems@tue.nl).

R. Cloudt is with the Powertrains Department, TNO Automotive, 5700 AT Helmond, The Netherlands (e-mail: robert.cloudt@tno.nl).

Color versions of one or more of the figures in this brief are available online at http://ieeexplore.ieee.org.

Digital Object Identifier 10.1109/TCST.2010.2057510

\author{
Variables \\ a Specific area for heat transfer $\left[\mathrm{m}^{-1}\right]$. \\ h Heat transfer coefficient $\left[\mathrm{Js}^{-1} \mathrm{~m}^{-2} \mathrm{~K}^{-1}\right]$. \\ $\mathrm{k}$ Pre-exponential factor. \\ $\dot{\mathrm{m}} \quad$ Mass flow $\left[\mathrm{kg} \mathrm{s}^{-1}\right]$. \\ $r \quad$ Reaction rate $\left[\mathrm{s}^{-1}\right]$. \\ $\mathrm{t}$ Time [s]. \\ v Gas velocity $\left[\mathrm{m} \mathrm{s}^{-1}\right]$. \\ $\mathrm{x} \quad$ Position along catalyst axis [m]. \\ C Concentration $\left[\mathrm{mol} \mathrm{m}^{-3}\right]$. \\ $\mathrm{C}_{\mathrm{p}} \quad$ Specific heat $\left[\mathrm{J} \mathrm{kg}^{-1} \mathrm{~K}^{-1}\right]$. \\ E Activation energy $\left[\mathrm{J} \mathrm{mol}^{-1}\right]$. \\ $\mathrm{H} \quad$ Reaction enthalpy [J]. \\ $\mathrm{R} \quad$ Universal gas constant $\left[\mathrm{J} \mathrm{mol}^{-1} \mathrm{~K}^{-1}\right]$. \\ SV Space velocity $\left[\mathrm{h}^{-1}\right]$. \\ $\mathrm{T}$ Temperature $[\mathrm{K}]$. \\ $\varepsilon \quad$ Catalyst porosity [-]. \\ $\theta \quad$ Ammonia surface coverage $[-]$. \\ $\theta^{*} \quad$ Critical ammonia surface coverage $[-]$. \\ $\rho \quad$ Density $\left[\mathrm{kg} \mathrm{m}^{-3}\right]$. \\ $\Omega \quad$ Adsorption capacity $\left[\mathrm{mol} \mathrm{m}^{-3}\right]$.
}

\section{INTRODUCTION}

$\mathbf{T}$ HE vast majority of European truck manufacturers apply urea-based selective catalytic reduction (SCR) technology to meet the current Euro-V emission targets. Due to the achievable high SCR $\mathrm{NO}_{x}$ conversion rates, this technology offers a fuel saving potential; engines can be calibrated for higher engine out nitrogen oxides $\left(\mathrm{NO}_{\mathrm{x}}\right)$ emissions (and corresponding lower fuel consumption, and thus lower $\mathrm{CO}_{2}$ emissions). In most cases, the desired SCR performance is realized by map-based feedforward control, see, e.g., [1], [2].

Future emission legislation requires further reduction of $\mathrm{NO}_{\mathrm{x}}$ and particulate matter (PM) emissions: additional $80 \%$ and $50 \%$ reductions to meet the proposed Euro-VI NO $\mathrm{x}_{\mathrm{x}}$ and PM targets, respectively. Low temperature performance has also to be optimized, since cold start emissions in the US transient cycle and the new World Harmonized Transient Cycle (WHTC) have to be considered. Furthermore, requirements for on-board diagnostics (OBD) and for in-use compliance have to be met. More precisely, limits on tailpipe $\mathrm{NO}_{\mathrm{x}}$ and ammonia $\left(\mathrm{NH}_{3}\right)$ emissions during real-world driving conditions and limits on performance degradation during useful life will be introduced. 


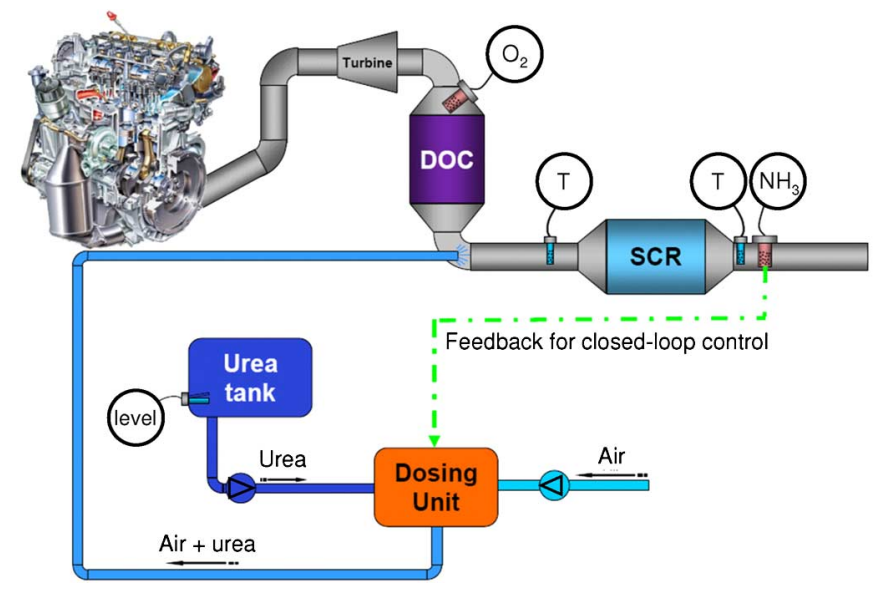

Fig. 1. Automotive urea SCR system layout [3].

With the need for high $\mathrm{NO}_{\mathrm{x}}$ conversion rates, SCR system control becomes challenging, since safety margins have to be reduced and dynamic performance becomes more important. In that case, the risk of unacceptable $\mathrm{NH}_{3}$ slip increases, especially for Zeolite-type catalysts, which are used in combination with particulate filters on US EPA 2010 and Euro-VI applications. In addition, the SCR control system has to be robust in order to meet in-use compliance and conformity of production requirements. A new model-based SCR control strategy is presented. It deals with the $\mathrm{NH}_{3}$ slip constraint by controlling the ammonia surface coverage on the catalyst. Using feedback information of an $\mathrm{NH}_{3}$ sensor, this strategy also offers robustness against system variance. This new strategy overcomes practical issues related to available cross-sensitive $\mathrm{NO}_{\mathrm{x}}$ sensors and to $\mathrm{NH}_{3}$ slip control for Zeolite-type catalysts. The potential of the $\mathrm{NH}_{3}$ sensor-based SCR control is demonstrated on an engine dynamometer.

\section{SCR SYSTEM DESCRIPTION}

Fig. 1 shows a typical layout of an automotive urea SCR system. In this system, three subsystems can be distinguished: the urea dosage system, catalyst system and control system. The dosage and catalyst subsystems will be discussed in more detail below. The control system is dealt with in Section III.

\section{A. Urea Dosage System}

To form the required reducing reagent for $\mathrm{NO}_{\mathrm{x}}$ reduction in the SCR catalyst, an aqueous urea solution (trade name: AdBlue) is injected through a nozzle, such that it is atomized in the exhaust pipe. The following main steps can be distinguished in the $\mathrm{NH}_{3}$ formation process:

$$
\begin{aligned}
& \mathrm{H}_{4} \mathrm{~N}_{2} \mathrm{CO} \rightarrow \mathrm{NH}_{3}+\mathrm{HNCO} \\
& \mathrm{HNCO}+\mathrm{H}_{2} \mathrm{O} \rightarrow \mathrm{NH}_{3}+\mathrm{CO}_{2} .
\end{aligned}
$$

Thermal decomposition (1) takes place upstream of the SCR catalyst. However, the amount of formed $\mathrm{NH}_{3}$ depends on temperature and space velocity (i.e., reciprocal of residence time) [4]. From measurements in a flow reactor, it is seen that the contribution of the hydrolysis reaction (2) to $\mathrm{NH}_{3}$ formation upstream of the SCR catalyst is negligible [5]. The hydrolysis needs to be catalyzed; it occurs inside the SCR catalyst.

\section{B. SCR Catalyst System}

Using the formed reagent $\left(\mathrm{NH}_{3}\right)$, the nitrogen oxides $\left(\mathrm{NO}_{\mathrm{x}}\right)$ emitted by the engine are reduced and converted to harmless products (nitrogen and water) over an SCR catalyst. This is realized according to the following reaction mechanisms:

$$
\begin{aligned}
& 4 \mathrm{NH}_{3}+4 \mathrm{NO}+\mathrm{O}_{2} \rightarrow \mathrm{N}_{2}+6 \mathrm{H}_{2} \mathrm{O} \\
& 4 \mathrm{NH}_{3}+2 \mathrm{NO}+2 \mathrm{NO}_{2} \rightarrow 4 \mathrm{~N}_{2}+6 \mathrm{H}_{2} \mathrm{O} \\
& 8 \mathrm{NH}_{3}+6 \mathrm{NO}_{2} \rightarrow 7 \mathrm{~N}_{2}+12 \mathrm{H}_{2} \mathrm{O} .
\end{aligned}
$$

The most desirable pathway is the "fast-SCR" reaction (4), which is considerably faster than the "standard SCR" reaction (3) and reaction (5). For high temperatures, maximal achievable $\mathrm{NO}_{\mathrm{x}}$ conversion can be limited due to $\mathrm{NH}_{3}$ oxidation

$$
\begin{aligned}
& \mathrm{NH}_{3}+5 \mathrm{O}_{2} \rightarrow 4 \mathrm{NO}+6 \mathrm{H}_{2} \mathrm{O} \\
& 4 \mathrm{NH}_{3}+3 \mathrm{O}_{2} \rightarrow 2 \mathrm{~N}_{2}+6 \mathrm{H}_{2} \mathrm{O} .
\end{aligned}
$$

\section{SCR System Model}

To model the studied SCR system, TNO's SIMCAT simulation package is used [6]-[8]. With this modular tool, various SCR system configurations can be modeled. It consists of 1-D models for urea decomposition in the exhaust pipe, pre-oxidation catalyst, diesel particulate filter (DPF), SCR catalyst, and $\mathrm{NH}_{3}$ oxidation catalyst. The SCR system model is based on first-principle modeling, including mass and energy balances, and is capable of real-time implementation on an automotive control unit (time step $=0.1 \mathrm{~s})$. The SCR system modeling approach used is similar to [9], [10]. A dedicated fit tool and test sequence is developed to fit the models based on engine test bench data [7], [8].

The new $\mathrm{NH}_{3}$ sensor-based control strategy comprises a realtime 1-D model, in which the SCR catalyst is divided into 12 longitudinal segments. In the applied model, the effect of urea decomposition on catalyst performance is assumed to be negligible. With the notation given in the nomenclature, general reaction rate expressions and a surface coverage limiting factor [10] are defined as

$$
k_{j}\left(T_{s}\right)=k_{j}^{0} e^{-E_{j} / R T_{s}} \quad f(\theta)=\theta^{*}\left[1-e^{-\theta / \theta^{*}}\right] .
$$

The desorption dynamics are assumed to follow Temkin-type desorption kinetics with surface coverage dependent activation energy [10]. For each segment, the $\mathrm{NH}_{3}$ surface coverage $\theta$ and substrate temperature $T_{s}$ dynamics are described by two coupled differential equations shown at the bottom of the page.

$$
\left.\left[\begin{array}{c}
\dot{\theta} \\
\dot{T}_{s}
\end{array}\right]=\left[\begin{array}{c}
k_{\mathrm{ads}}\left(T_{s}\right) C_{N H_{3}}[1-\theta]-\left[k_{\mathrm{des}}\left(T_{s}\right)+k_{\mathrm{oxno}}\left(T_{s}\right)+k_{\mathrm{oxn} 2}\left(T_{s}\right)\right] \theta \\
-\left[k_{s t}\left(T_{s}\right) C_{N O}+2 k_{f a}\left(T_{s}\right) C_{N O} C_{N O_{2}}+\frac{4}{3} k_{s l}\left(T_{s}\right) C_{N O_{2}}\right] f(\theta) \\
\frac{1}{(1-\varepsilon) \rho_{s} C_{p, s}}\left[h_{g s} a_{g s}\left(T_{g}-T_{s}\right)-h_{s a} a_{s a}\left(T_{s}-T_{a}\right)+\Omega \sum_{j} r_{j} \Delta H_{j}\right.
\end{array}\right]\right]
$$


TABLE I

OVERVIEW OF AdVANCED SCR CONTROL STUdies ( FF = FEEDForWARD CONTROLLER; ESC = EUROPEAN STEAdY-STATE CYCLE; ETC $=$ EUROPEAN TRANSIENT CyCle; FTP = US TRANSIENT CYCLE; JE05 = JAPANESE TRANSIENT CYCLE; Non-Cross-SENSITIVE $=$ COMPENSATION FOR NH $_{3}$ Cross-SENSITIVITY OF $\mathrm{NO}_{\mathrm{x}}$ SENSOR)

\begin{tabular}{|c|c|c|c|c|c|c|c|}
\hline Ref. & Affiliation & Engine & $\begin{array}{c}\text { SCR } \\
\text { catalyst } \\
\text { type }\end{array}$ & Controller & Model & $\begin{array}{c}\text { Feedback } \\
\text { information }\end{array}$ & Test \\
\hline$[1]$ & $\begin{array}{c}\text { Engelhard/ } \\
\text { TNO }\end{array}$ & & & $\mathrm{FF}$ & $\begin{array}{l}2^{\text {nd }} \text { order filter } \\
\left(\mathrm{T}_{\mathrm{cat}}, \mathrm{NO}_{\mathrm{x}, \text { engine }}\right)\end{array}$ & & ETC \\
\hline$[2]$ & Bosch & $\begin{array}{c}\text { 6-cyl. HD } \\
\text { diesel }\end{array}$ & & FF & $\begin{array}{l}\text { Time delay }+1^{\text {st }} \text { order filter } \\
\qquad\left(\mathrm{T}_{\text {cal }}, \mathrm{NO}_{\mathrm{x}, \text { engine }}\right)\end{array}$ & & ETC \\
\hline $\begin{array}{l}4, \\
11]\end{array}$ & ETH Zurich & $\begin{array}{c}10 \ell, 6 \text {-cyl. } \\
\text { Liebherr D926 }\end{array}$ & $\begin{array}{c}\text { Vanadium } \\
(19.9 \ell)\end{array}$ & $\begin{array}{c}\text { Model-based FF + PI } \\
\text { control }\end{array}$ & $\begin{array}{c}\text { Cat temp. }+\mathrm{NH}_{3} \text { surface } \\
\text { coverage }\end{array}$ & $\begin{array}{c}\text { Cross-sensitive } \\
\mathrm{NO}_{\mathrm{x}}\end{array}$ & $\begin{array}{l}\text { Load steps, } \\
\text { ESC, ETC }\end{array}$ \\
\hline$[12]$ & $\begin{array}{l}\text { Michigan Tech/ } \\
\text { International }\end{array}$ & $\begin{array}{l}7.6 \ell, 6 \text {-cyl. } \\
\text { Navistar I6 }\end{array}$ & Fe-Zeolite & $\begin{array}{l}\text { Observer-based non- } \\
\text { linear state feedback }\end{array}$ & $\mathrm{NH}_{3}$ surface coverage & $\begin{array}{c}\text { Non-cross-sensitive } \\
\mathrm{NO}_{\mathrm{x}}\end{array}$ & Load steps \\
\hline$[13]$ & $\begin{array}{l}\text { Delft University } \\
\text { of Technology }\end{array}$ & $\begin{array}{c}\text { 3-cyl. LPW3, } \\
8 \mathrm{~kW}\end{array}$ & $\begin{array}{c}\text { Vanadium } \\
(1.05 \ell)\end{array}$ & Model-based FF & Neural net engine-out $\mathrm{NO}_{\mathrm{x}}$ & & Stationary \\
\hline$[14]$ & Cummins & & & $\begin{array}{l}\text { Model-based FF + gain } \\
\text { scheduled PI control }\end{array}$ & $\begin{array}{c}\text { Time delay }+1^{\text {st }} \text { order lead/lag } \\
\text { filter (catalyst dynamics) }\end{array}$ & $\begin{array}{c}\text { Non-cross-sensitive } \\
\mathrm{NO}_{\mathrm{x}}\end{array}$ & Step \\
\hline$[15]$ & Ford & & & $\begin{array}{c}\text { FF + observer-based } \\
\text { feedback }\end{array}$ & $\mathrm{NH}_{3}$ surface coverage & $\begin{array}{c}\text { Non-cross-sensitive } \\
\mathrm{NO}_{\mathrm{x}}\end{array}$ & \\
\hline$[16]$ & Cummins & $\begin{array}{l}15 \ell, 6-\text { cyl. } \\
\text { ISX-450 }\end{array}$ & Vanadium & $\begin{array}{l}\text { Model Reference } \\
\text { Adaptive Control }\end{array}$ & $\begin{array}{c}1^{\text {st }} \text { order filter } \\
\text { (catalyst dynamics) }\end{array}$ & $\begin{array}{c}\text { Non-cross-sensitive } \\
\mathrm{NO}_{\mathrm{x}}\end{array}$ & Hot FTP \\
\hline$[17]$ & Ford & & & Sliding mode control & $\mathrm{NH}_{3}$ surface coverage & $\mathrm{NO}_{\mathrm{x}}$ & FTP \\
\hline$[18]$ & Waseda univ. & $\begin{array}{c}4 \ell, 4 \text {-cyl. } \\
\text { Diesel }\end{array}$ & $\begin{array}{l}\text { Zeolite } \\
(4.3 \ell)\end{array}$ & $\mathrm{FF}$ & $\begin{array}{c}\text { Temperature-based } \mathrm{NH}_{3} \\
\text { surface coverage compensation }\end{array}$ & & JE05 \\
\hline [19] & Honda & & & $\begin{array}{c}\text { Minimum seeking } \\
\text { control }\end{array}$ & & $\begin{array}{c}\text { Cross-sensitive } \\
\mathrm{NO}_{\mathrm{x}}\end{array}$ & \\
\hline
\end{tabular}

For a segment, the model state $x$, input $u$ and output $y$ are given by

$$
\begin{aligned}
x^{T} & =\left[\begin{array}{ll}
\theta & T_{s}
\end{array}\right] \\
u^{T} & =\left[\begin{array}{ll}
C_{\mathrm{NO}, \text { in }} & C_{\mathrm{NO}_{2}, \text { in }} C_{\mathrm{NH}_{3}, \text { in }} T_{g, \text { in }} T_{a} \dot{m}_{\mathrm{exh}}
\end{array}\right] \\
y^{T} & =\left[C_{\mathrm{NO}, \text { out }} C_{\mathrm{NO}_{2}, \text { out }} C_{\mathrm{NH}_{3}, \text { out }} T_{g, \text { out }}\right] .
\end{aligned}
$$

Assuming quasi-stationary conditions, the spatial concentrations for $\mathrm{NO}, \mathrm{NO}_{2}$, and $\mathrm{NH}_{3}$ are determined from the mass balances of the gaseous species

$$
\begin{aligned}
& v \frac{\partial C_{\mathrm{NO}}}{\partial x}=-\Omega\left[k_{s t}\left(T_{s}\right) C_{\mathrm{NO}} f(\theta)+k_{f a}\left(T_{s}\right) C_{\mathrm{NO}} C_{\mathrm{NO}_{2}} f(\theta)\right. \\
& \left.-k_{\text {oxno }}\left(T_{s}\right) \theta\right] \\
& v \frac{\partial C_{\mathrm{NO}_{2}}}{\partial x}=-\Omega\left[k_{s l}\left(T_{s}\right) C_{\mathrm{NO}_{2}} f(\theta)\right. \\
& \left.+k_{f a}\left(T_{s}\right) C_{\mathrm{NO}} C_{\mathrm{NO}_{2}} f(\theta)\right] \\
& v \frac{\partial C_{\mathrm{NH}_{3}}}{\partial x}=-\Omega\left[k_{\mathrm{ads}}\left(T_{s}\right) C_{\mathrm{NH}_{3}}(1-\theta)-k_{\mathrm{des}}\left(T_{s}\right) \theta\right] \text {. }
\end{aligned}
$$

The exhaust gas temperature varies over the catalyst length $x$ according to

$$
v \frac{\partial T_{g}}{\partial x}=-\frac{1}{\varepsilon \rho_{g} C_{p, g}} h_{g s} a_{g s}\left(T_{g}-T_{s}\right) .
$$

\section{SCR CONTROL}

\section{A. Overview of SCR Control Strategies}

Table I gives a brief overview of the progress in SCR control development. It is based on studies found in the open literature. Whenever available, details about the engine, SCR system, control system, and tests are listed.

1) Feedforward SCR Controller: Map-based urea dosage strategies are the current standard in vehicles, see, e.g., [1], [2], [5]. These feedforward strategies have proven to be sufficient to meet Euro-IV and Euro-V emission standards. They are inspired on steady-state operation of the SCR catalyst and basically adjust the $\mathrm{NH}_{3}$ to $\mathrm{NO}_{\mathrm{x}}$ stoichiometric dosing ratio (NSR). Simple model functionality is incorporated to improve catalyst 

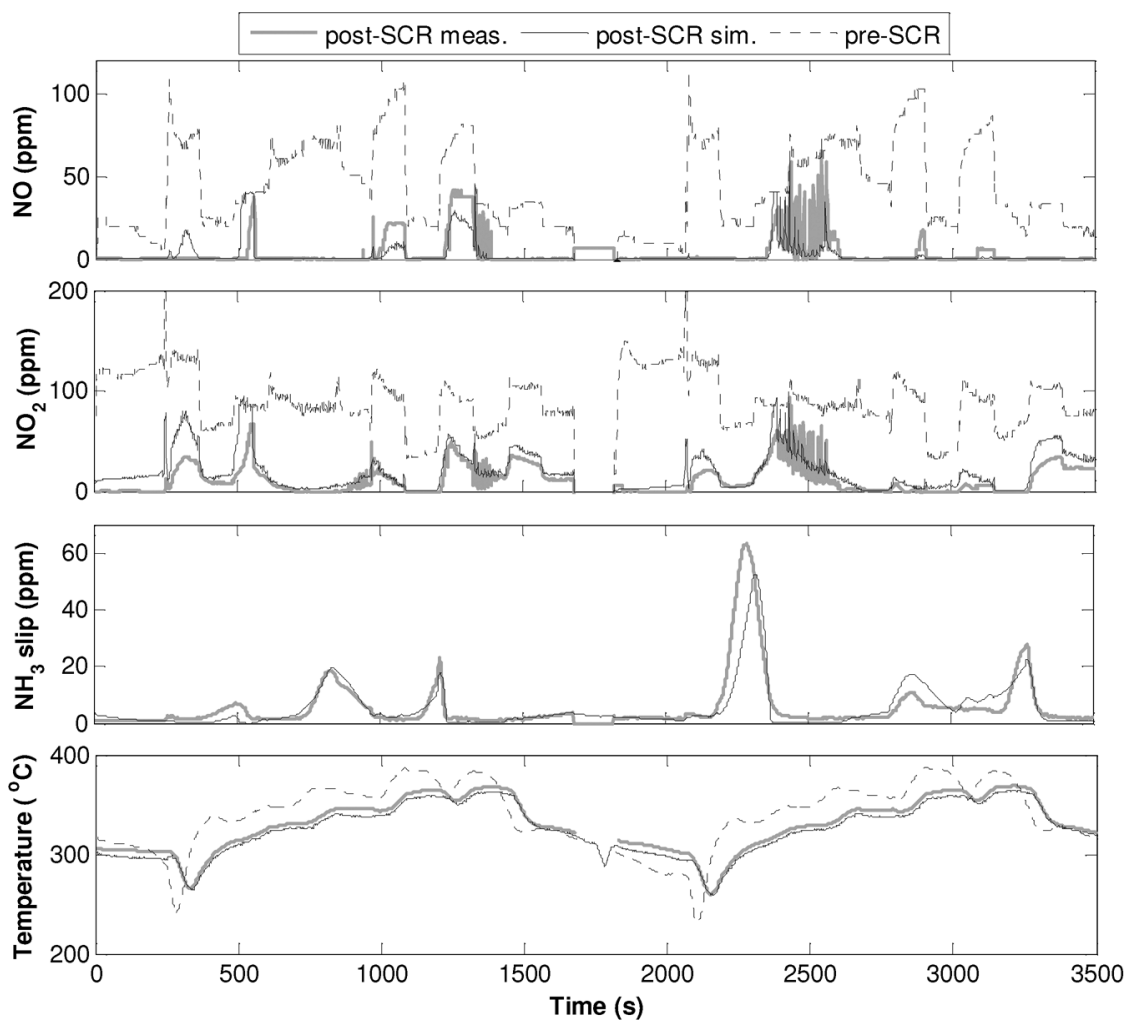

Fig. 2. Model fit results for two consecutive European steady-state cycles (ESC).

temperature prediction [1], [2], improve engine-out $\mathrm{NO}_{\mathrm{x}}$ prediction [1], [2], [13], or as a crude model of the SCR catalyst dynamics [2], [14].

Driven by the required increasing $\mathrm{NO}_{\mathrm{x}}$ reduction rates and introduction of Zeolite catalysts, research focuses on $\mathrm{NH}_{3}$ surface coverage control to maintain high $\mathrm{NO}_{\mathrm{x}}$ conversion in combination with decent control over the $\mathrm{NH}_{3}$ slip. In its simplest form, the feedforward urea dosing is compensated for the amount of $\mathrm{NH}_{3}$ desorbed during a temperature rise [18]. Improved $\mathrm{NH}_{3}$ slip control is provided by strategies comprising a first principles, reduced order model for the $\mathrm{NH}_{3}$ surface coverage, e.g., [4], [12], [15].

2) Feedback SCR Controllers: Due to reduced safety margins and robustness issues, feedback SCR control attracts considerable attention. Most feedback strategies rely on PI control or on a surface coverage observer with state feedback control. It is noted that other control approaches are found too: model reference adaptive control [16], sliding mode control [17], and minimum seeking control [19]. Currently available $\mathrm{NO}_{\mathrm{x}}$ sensors are cross-sensitive to $\mathrm{NH}_{3}$, which poses potential instability problems when not addressed correctly. The cross-sensitivity of $\mathrm{NO}_{\mathrm{x}}$ sensors is dealt with in [4], [11], [19]. Experimental results of a strategy based on perturbation of the urea injection are presented in [4] and [11] for a setup comprising a Vanadium SCR catalyst.

\section{B. Tested SCR Control Strategies}

In this work, a new adaptive strategy for combined surface coverage and $\mathrm{NH}_{3}$ slip control is presented. With the recent availability of an $\mathrm{NH}_{3}$ sensor [3], [20], the opportunity of adjusting the urea injection based on $\mathrm{NH}_{3}$ slip feedback information becomes feasible. The $\mathrm{NH}_{3}$ surface coverage part of the strategy is based on a high-fidelity real-time first principles model, as is described in Section II. The model fit results for two consecutive ESC are shown in Fig. 2. Due to on-board diagnostics requirements, engines will be equipped with a tailpipe $\mathrm{NO}_{\mathrm{x}}$ sensor. This sensor could also be used for SCR control. In this study, this new adaptive surface coverage and $\mathrm{NH}_{3}$ slip control strategy is compared with a more traditional map-based strategy extended with a $\mathrm{NO}_{\mathrm{x}}$ sensor feedback scheme.

1) $\mathrm{NH}_{3}$ Sensor-Based Control: Closed-loop $\mathrm{NH}_{3}$ control is attractive, because maximum $\mathrm{NO}_{\mathrm{x}}$ conversion is pursued under a given $\mathrm{NH}_{3}$ slip constraint. From Fig. 3, it can be concluded that under low or decreasing temperature conditions, $\mathrm{NH}_{3}$ slip feedback control tends to load the SCR catalyst with ammonia, especially for Zeolite-type SCR catalysts. Although high $\mathrm{NH}_{3}$ surface coverage is beneficial for $\mathrm{NO}_{\mathrm{x}}$ conversion, it can cause $\mathrm{NH}_{3}$ slip peaks during an increase of the catalyst temperature. Therefore, this surface coverage has to be controlled to a level that is safe from causing unacceptable $\mathrm{NH}_{3}$ slip peaks, but does maintain considerable $\mathrm{NO}_{\mathrm{x}}$ conversion.

The applied SCR control strategy is illustrated in Fig. 4. This strategy combines the following two control modes.

- $\mathrm{NH}_{3}$ Surface Coverage Control: Using the 1-D SCR model described in Section II, the spatial distribution of the $\mathrm{NH}_{3}$ surface coverage, $\theta$, is estimated online. The averaged value $\theta_{\text {avg }}$ over the 12 longitudinal segments is compared with a reference value $\theta_{\text {ref }}\left(T_{s}\right)$. This is essentially the maximum allowable $\mathrm{NH}_{3}$ storage (see 


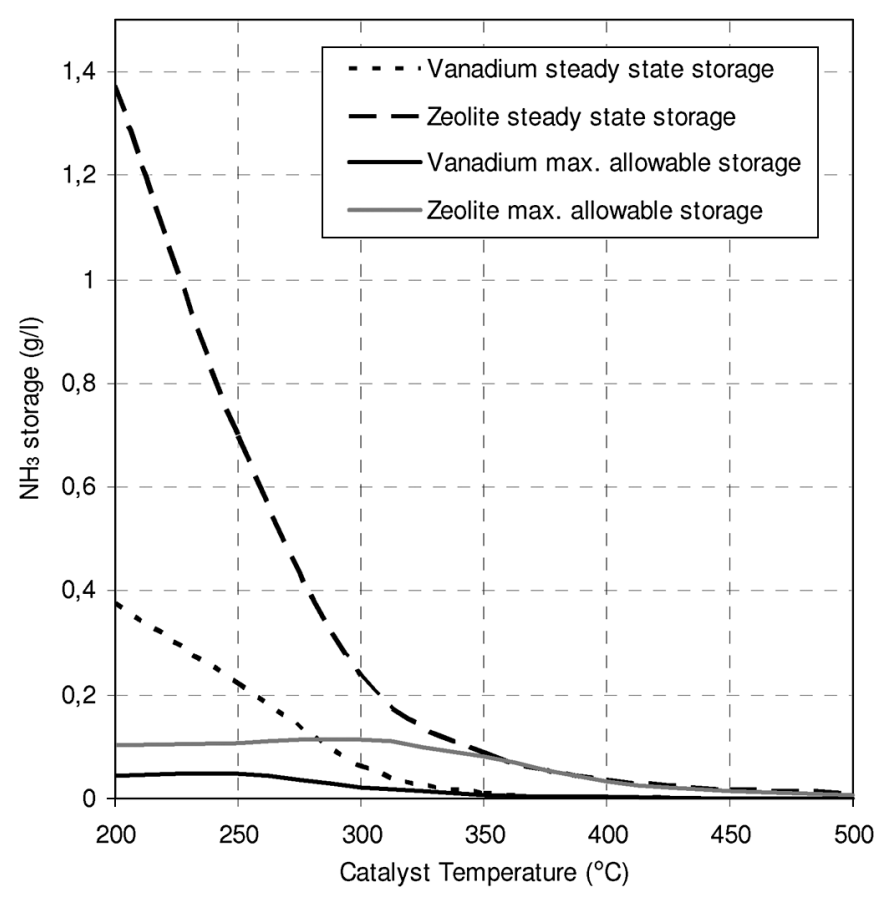

Fig. 3. Steady-state and maximum allowable $\mathrm{NH}_{3}$ storage as a function of catalyst temperature, for a 34-liter SCR catalyst, space velocity $=5000 \mathrm{~h}^{-1}$, $\mathrm{NSR}=1.2$ and engine-out $\mathrm{NO}_{x}=250 \mathrm{~g} / \mathrm{h}$. Maximal allowable storage is the $\mathrm{NH}_{3}$ storage amount that causes an $\mathrm{NH}_{3}$ slip peak of $25 \mathrm{ppm}$ at a simulated worst-case temperature increase of $5^{\circ} \mathrm{C} / \mathrm{s}$.

Fig. 3), which results in a 25 ppm $\mathrm{NH}_{3}$ slip peak during a worst-case temperature increase [21]. A PI controller adjusts the urea dosage to track the reference coverage $\theta_{\text {ref }}$.

- $\mathrm{NH}_{3}$ Slip Feedback Control: $\mathrm{NH}_{3}$ slip feedback information is used to directly adjust the urea injection to control the $\mathrm{NH}_{3}$ slip towards the reference concentration level $\mathrm{NH}_{3 \text {,ref }}$ using a PID controller. The average $\mathrm{NH}_{3}$ slip has to be below $10 \mathrm{ppm}$. Here, we used $\mathrm{NH}_{3 \text {,ref }}$ of $8 \mathrm{ppm}$ for safety.

Both controllers contain integrator anti-wind up. The controller switches between $\mathrm{NH}_{3}$ slip feedback control mode and $\mathrm{NH}_{3}$ surface coverage control mode, depending on the measured $\mathrm{NH}_{3}$ slip and estimated averaged surface coverage. This is shown in the equation at the bottom of the page, where $E_{\theta}=\theta_{\text {ref }}\left(T_{s}\right)-\theta_{\text {avg }}, E_{\mathrm{NH}_{3}}=\mathrm{NH}_{3, \text { ref }}-\mathrm{NH}_{3, \text { meas }}$ and $U(s)$ the Laplace transform of the urea solution dosing rate $u$ (in $\mathrm{g} / \mathrm{h}$ ). The $\mathrm{NH}_{3}$ slip control mode is triggered when the reference value $\mathrm{NH}_{3 \text {,ref }}$ is exceeded. However, $\theta$ control always has the highest priority $\left(\theta_{\mathrm{avg}}>\theta_{\mathrm{ref}}\left(T_{s}\right)\right)$, since unacceptable ammonia loading has to be avoided. Urea dosing is kept constant through bumpless transfer when switching control mode.

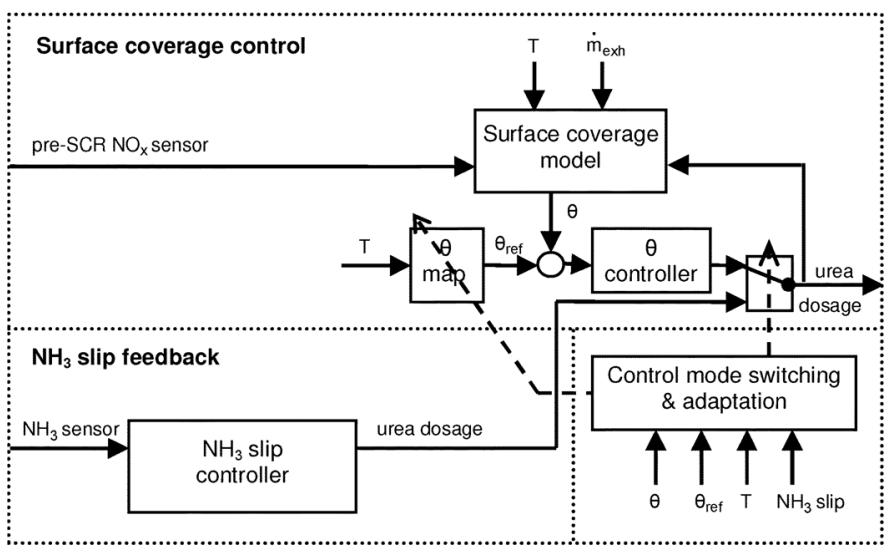

Fig. 4. Block scheme of TNO's adaptive surface coverage and $\mathrm{NH}_{3}$ slip control strategy.

TABLE II

OVERVIEW OF APPLIED CONTROL GAINS

\begin{tabular}{|ll|}
\hline$\theta$ control & $\mathrm{NH}_{3}$ slip control \\
\hline$K_{P, \theta}=6.3 \cdot 10^{4} \mathrm{~g} \mathrm{~h}^{-1}$ & $K_{P, N H_{3}}=0.015 \mathrm{~g} \mathrm{~h}^{-1} \mathrm{ppm}^{-1}$ \\
$K_{I, \theta}=1.9 \cdot 10^{3} \mathrm{~g} \mathrm{~h}^{-1} \mathrm{~s}^{-1}$ & $K_{I, N H_{3}}=3 \cdot 10^{-4} \mathrm{~g} \mathrm{~h}^{-1} \mathrm{ppm}^{-1} \mathrm{~s}^{-1}$ \\
& $K_{D, N H_{3}}=10 \mathrm{~g} \mathrm{~h}^{-1} \mathrm{ppm}^{-1} \mathrm{~s}$ \\
& $\tau=20 \mathrm{~s}$ \\
\hline
\end{tabular}

To enhance the robustness of the proposed strategy, the $\theta_{\text {ref }}$ map is scaled by an adaptation factor. This map is adapted such that the $\mathrm{NH}_{3}$ slip feedback control mode is active during high and increasing catalyst temperatures (where $\mathrm{NH}_{3}$ slip is expected or $\mathrm{NH}_{3}$ slip feedback control is feasible) and $\mathrm{NH}_{3}$ surface coverage control is active in all other cases. A more detailed description of the adaptation mechanism is given in [21].

The controller is parameterized by manual tuning at the test stand; the applied control gains are listed in Table II. The rate of adaptation was calibrated such that $\theta_{\text {ref }}$ can decrease with $1 \%$ per second relative to the original $\theta_{\text {ref }}$ map, and increase with $0.5 \%$ per second. Note that the adaptation capabilities of the proposed control strategy are heavily dependent on the behavior of the SCR catalyst temperature.

2) $N O_{X}$ Sensor-Based Control: The applied $\mathrm{NO}_{\mathrm{x}}$ sensorbased strategy consists of a feedforward part that applies urea injection based on an engine-out $\mathrm{NO}_{\mathrm{x}}$ signal, nominal stoichiometric ratio (NSR) map and a dynamic $\mathrm{NH}_{3}$ desorption compensation. The dosing signal is corrected using feedback information from the post-SCR $\mathrm{NO}_{\mathrm{x}}$ sensor. To prevent the feedback control loop from becoming unstable, the $\mathrm{NH}_{3}$ cross-sensitivity of the $\mathrm{NO}_{\mathrm{x}}$ sensor has to be taken into consideration. The applied cross-sensitivity compensation is based on the filtering effect of the SCR catalyst on tailpipe emissions. By applying a pulsating urea flow, amplitudes of a couple of ppm for the pulses

$$
U(s)= \begin{cases}{\left[K_{P, \theta}+\frac{K_{I, \theta}}{s}\right] E_{\theta}(s),} & \text { if } \quad \theta_{\text {avg }}>\theta_{\text {ref }}\left(T_{s}\right) \\ {\left[K_{P, \mathrm{NH}_{3}}+\frac{K_{I, \mathrm{NH}_{3}}}{s}+\frac{K_{D, \mathrm{NH}_{3}} s}{\tau s+1}\right] E_{\mathrm{NH}_{3}}(s),} & \text { if } \quad \mathrm{NH}_{3, \text { meas }}>\mathrm{NH}_{3, \text { ref }} \text { and } \theta_{\mathrm{avg}} \leq \theta_{\text {ref }}\left(T_{s}\right)\end{cases}
$$




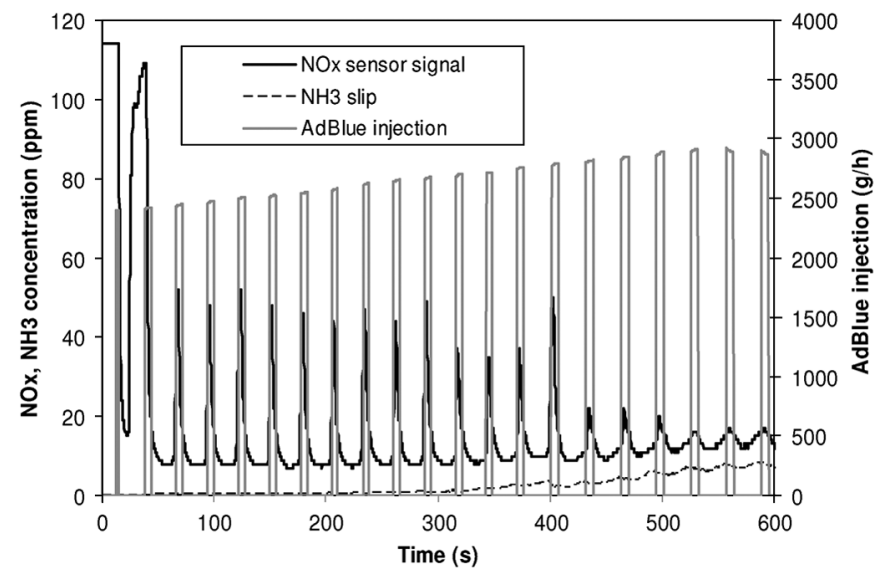

Fig. 5. Experimental demonstration of post-SCR NO $\mathrm{N}_{\mathrm{x}}$ sensor behavior for pulsating urea flow with Fe-Zeolite catalyst.

in the $\mathrm{NO}_{\mathrm{x}}$ concentration signal are pursued. If the pulses are too high, the algorithm increases the urea injection. If they are too small, $\mathrm{NH}_{3}$ slip is likely, and the algorithm reduces the nominal urea injection. Alternative strategies can be found in, e.g., [4], [11], [19].

This principle has proven to function, but requires stationary operating conditions for adaptation. The variations in the $\mathrm{NO}_{\mathrm{x}}$ sensor signal have to be clearly linked to the pulsating urea flow and not to a change of the engine operating point. Moreover, the proposed $\mathrm{NO}_{\mathrm{x}}$ based control strategy requires a fast response to variations of the urea injection. Consequently, it requires a high SCR temperature $\left(>330^{\circ} \mathrm{C}\right)$ in order to apply the feedback correction.

The requirement for stationary conditions severely limits the robustness and applicability of feedback control using a crosssensitive $\mathrm{NO}_{\mathrm{x}}$ sensor. Furthermore, the proposed strategy does not offer any control over the absolute $\mathrm{NH}_{3}$ slip level; it relies on the correlation between the filtering effect of the SCR catalyst on the fluctuating emissions and the occurrence of $\mathrm{NH}_{3}$ slip. Compared to the studies in [4] and [11], a much larger perturbation of the urea injection was necessary for the studied engine and Fe-Zeolite SCR catalyst combination. This ultimately led to the pulsating urea delivery shown in Fig. 5. More details about the proposed $\mathrm{NO}_{\mathrm{x}}$-based strategy can be found in [21]

\section{Engine Test Results}

\section{A. Test Setup}

The test setup comprises: 1) a 12-liter heavy-duty diesel engine equipped with exhaust gas recirculation (EGR);2) a catalyzed diesel particulate filter (CDPF) with an upstream diesel oxidation catalyst (DOC); and 3) a 34-liter Fe-Zeolite SCR system with air-assisted urea dosage system. The SCR catalyst and urea injection point are located downstream of the CDPF. $\mathrm{NO}_{\mathrm{x}}$ and $\mathrm{NH}_{3}$ sensors are installed on the locations that are depicted in Fig. 6.

Engine-out $\mathrm{NO}_{\mathrm{x}}$ levels comply with US 2007 standard. TNO's urea dosage strategy and real-time SCR model are implemented on a rapid prototyping controller, which communicates with the engine $\mathrm{ECU}$, dosing system and $\mathrm{NH}_{3}$ and $\mathrm{NO}_{\mathrm{x}}$ sensors through CAN interfaces. The SCR model has been

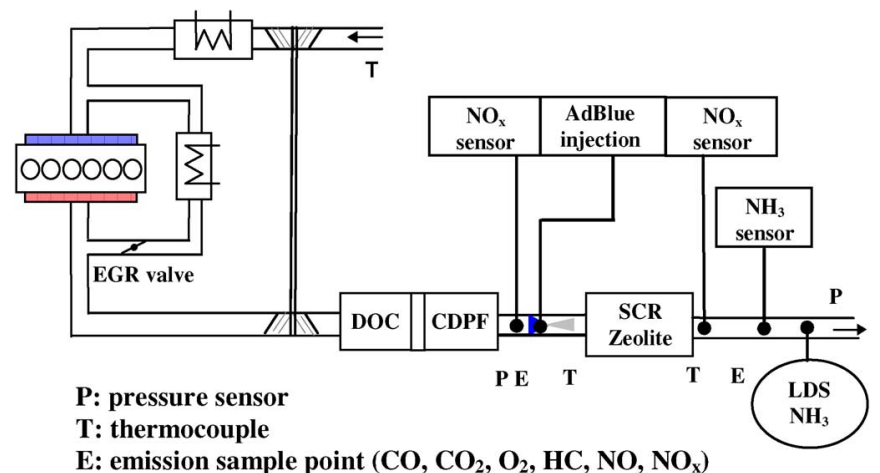

Fig. 6. Scheme of test setup (LDS = laser diode spectrometer).

TABLE III

Measured Cycle Results for $\mathrm{NH}_{3}$ Sensor-Based Control Strategy IN CASE OF 30\% UREA OVER-Dosage

\begin{tabular}{|c|c|c|c|}
\hline \multirow{2}{*}{ Test cycle } & $\begin{array}{c}\mathrm{NO}_{\mathrm{x}} \\
\text { conv. }\end{array}$ & $\begin{array}{c}\text { Avg. } \\
\mathrm{NH}_{3} \text { slip }\end{array}$ & $\begin{array}{c}\max \\
\mathrm{NH}_{3} \text { slip }\end{array}$ \\
\cline { 2 - 4 } & $\%$ & $\mathrm{ppm}$ & $\mathrm{ppm}$ \\
\hline $1^{\text {st }} \mathrm{ESC}$ & 88 & 13 & 79 \\
\hline $2^{\text {nd }} \mathrm{ESC}$ & 90 & 7 & 26 \\
\hline $3^{\text {rd }} \mathrm{ESC}$ & 91 & 6 & 24 \\
\hline $1^{\text {st }} \mathrm{ETC}$ & 87 & 6 & 38 \\
\hline $2^{\text {nd }} \mathrm{ETC}$ & 84 & 2 & 14 \\
\hline $3^{\text {rd }} \mathrm{ETC}$ & 72 & 1 & 4 \\
\hline
\end{tabular}

fitted to the applied Fe-Zeolite SCR catalyst in the test setup, based on experimental data from engine dynamometer tests [6], [7]. The model and measurement show good agreement (see Fig. 2); the model error for $\mathrm{NO}_{\mathrm{x}}$ conversion is less than $5 \%$ over two ESC tests and the error in average and peak $\mathrm{NH}_{3}$ slip is less then 1 and $10 \mathrm{ppm}$, respectively. More especially, the accurate $\mathrm{NH}_{3}$ slip prediction gives confidence about the accuracy of the online $\mathrm{NH}_{3}$ storage estimation.

\section{B. Adaptive Surface Coverage and $\mathrm{NH}_{3}$ Slip Control Performance}

To validate the $\mathrm{NH}_{3}$ sensor-based control strategy, it has been tested on both the European steady-state cycle (ESC) and the European transient cycle (ETC). As a disturbance, 30\% urea over-dosage was applied. This represents any disturbance source which can cause an increased $\mathrm{NH}_{3}$ slip, like, e.g., SCR catalyst ageing or inaccuracy in urea dosing, in exhaust flow determination or in pre-SCR $\mathrm{NO}_{\mathrm{x}}$ signal. Several consecutive test cycles were run to investigate whether the $\mathrm{NH}_{3}$ sensor-based control strategy is capable of compensating for the $30 \%$ increased urea injection. An overview of the test cycle results is given in Table III.

Fig. 7 illustrates the actions of the proposed $\mathrm{NH}_{3}$ sensorbased control strategy for three consecutive ESC. In the first ESC test, $30 \%$ urea over-dosage results in a 79 ppm NH 3 slip peak. Every time the measured $\mathrm{NH}_{3}$ slip exceeds the $\mathrm{NH}_{3}$ slip reference level, the algorithm switches from surface coverage 

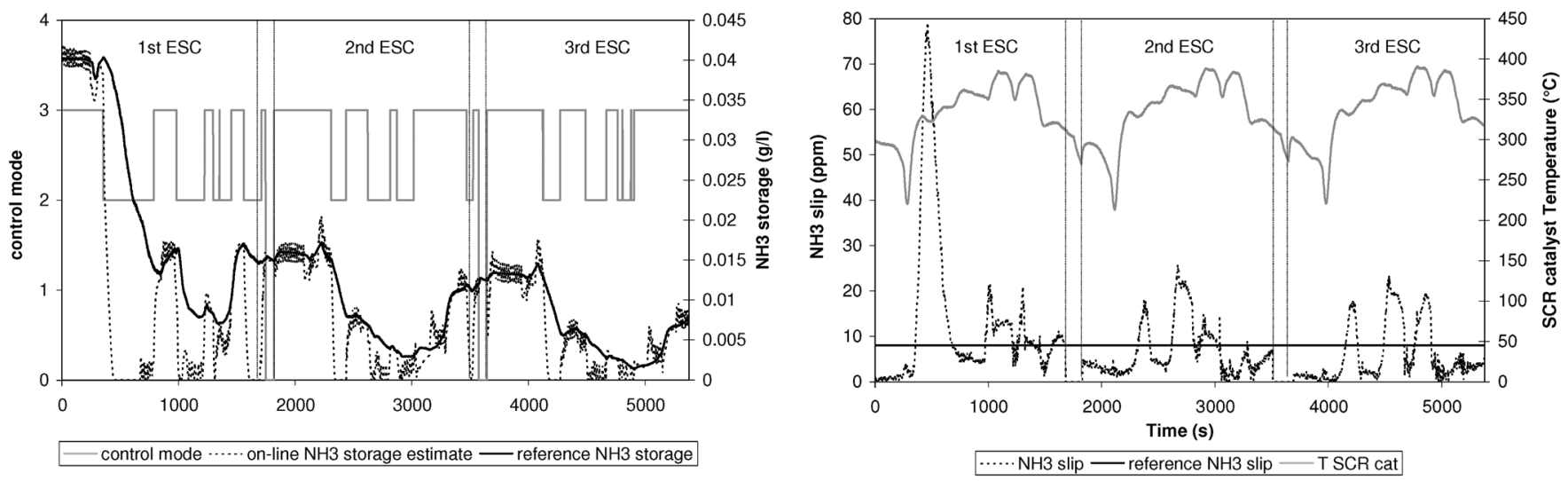

Fig. 7. Control and adaptation behavior of the $\mathrm{NH}_{3}$ based control strategy on three consecutive ESC with $30 \%$ urea over-dosage. (Control mode: $0=$ no injection, $2=\mathrm{NH}_{3}$ slip feedback control, $3=$ surface coverage control).

control to $\mathrm{NH}_{3}$ slip feedback control. If $\mathrm{NH}_{3}$ slip feedback control is active during a period where $\mathrm{NH}_{3}$ slip is undesired (temperature dependent), the algorithm reacts by lowering the desired SCR $\mathrm{NH}_{3}$ storage in the $\theta$ map. These actions are clearly visible in Fig. 7; the reference $\mathrm{NH}_{3}$ storage level for the online SCR model is reduced by more than a factor 2 during the first ESC. Finally, the peak $\mathrm{NH}_{3}$ slip drops from 79 to $24 \mathrm{ppm}$ in the third ESC. The realized $\mathrm{NH}_{3}$ emissions meet the targets set in this study: peak and average $\mathrm{NH}_{3}$ slip of 25 and $10 \mathrm{ppm}$, respectively.

The proposed control strategy also gives good results during ETC test conditions (see Table III); the peak $\mathrm{NH}_{3}$ slip drops from 38 to $4 \mathrm{ppm}$ within three consecutive cycles. These extremely low $\mathrm{NH}_{3}$ slip values compromise on $\mathrm{NO}_{\mathrm{x}}$ conversion.

\section{Comparison With $\mathrm{NO}_{x}$ Sensor-Based Strategy}

For ESC, the performance of the adaptive surface coverage and $\mathrm{NH}_{3}$ slip control strategy is compared with the performance of the map-based strategy with $\mathrm{NO}_{\mathrm{x}}$ sensor feedback. Note that this comparison can only be made on the ESC, since the presented $\mathrm{NO}_{\mathrm{x}}$ based strategy is not applicable to the transient conditions in the ETC. Consecutive ESC with both $30 \%$ urea dilution and $30 \%$ urea overdosing were tested to observe the robustness of these control strategies. The results of these tests are presented in Table IV.

In Fig. 7, it has already been illustrated that the $\mathrm{NH}_{3}$ based control strategy is capable of adaptation to the $30 \%$ urea overdosage. The strategy lowers the desired $\mathrm{NH}_{3}$ storage level for the online SCR model, which results in less $\mathrm{NH}_{3}$ slip. For the $30 \%$ dilution case, the algorithm increases the reference $\mathrm{NH}_{3}$ storage level for the online SCR model, as can be seen in Fig. 8. This causes the peak $\mathrm{NH}_{3}$ slip to increase from 9 to $15 \mathrm{ppm}$ during the four ESC, which is well within the $25 \mathrm{ppm}$ peak $\mathrm{NH}_{3}$ limit.

The $\mathrm{NO}_{\mathrm{x}}$ based SCR control strategy is also capable of adaptation for the applied disturbances of urea injection. In case of the $30 \%$ higher urea injection, the $\mathrm{NO}_{\mathrm{x}}$-based algorithm reduces the peak $\mathrm{NH}_{3}$ slip in the ESC from 44 to $24 \mathrm{ppm}$, while maintaining a $\mathrm{NO}_{x}$ conversion of roughly $90 \%$. Fig. 9 shows the adaptation behavior of the $\mathrm{NO}_{\mathrm{x}}$-based algorithm for the $30 \%$ urea dilution case. The correction factor on the stoichio-
TABLE IV

MEASUREd ESC RESUlts FOR $\mathrm{NO}_{\mathrm{x}}$ AND $\mathrm{NH}_{3}$-BASEd CONTROL STRATEGIES IN CASE of 30\% UREa Dilution and 30\% UREa OVERDosage

\begin{tabular}{|c|c|c|c|c|c|}
\hline \multicolumn{6}{|c|}{ Measurements } \\
\hline \multirow[t]{2}{*}{$\begin{array}{l}\text { Control } \\
\text { strategy }\end{array}$} & \multirow[t]{2}{*}{ Disturbance } & \multirow[t]{2}{*}{$\begin{array}{c}\text { ESC } \\
\#\end{array}$} & $\begin{array}{l}\mathrm{NO}_{\mathrm{x}} \\
\text { conv. }\end{array}$ & $\begin{array}{l}\text { Avg. } \\
\mathrm{NH}_{3} \\
\text { slip }\end{array}$ & $\begin{array}{l}\max \\
\mathrm{NH}_{3} \\
\text { slip }\end{array}$ \\
\hline & & & $\%$ & ppm & ppm \\
\hline \multirow{3}{*}{$\begin{array}{l}\mathrm{NH}_{3^{-}} \\
\text {based }\end{array}$} & \multirow[t]{3}{*}{$30 \%$ over-dosage } & 1 & 88 & 13 & 79 \\
\hline & & 2 & 90 & 7 & 26 \\
\hline & & 3 & 91 & 6 & 24 \\
\hline \multirow{4}{*}{$\begin{array}{l}\mathrm{NH}_{3^{-}} \\
\text {based }\end{array}$} & \multirow[t]{4}{*}{$30 \%$ dilution } & 1 & 90 & 3 & 9 \\
\hline & & 2 & 92 & 3 & 10 \\
\hline & & 3 & 92 & 5 & 11 \\
\hline & & 4 & 92 & 5 & 15 \\
\hline \multirow{4}{*}{$\begin{array}{l}\mathrm{NO}_{\mathrm{x}^{-}} \\
\text {based }\end{array}$} & \multirow[t]{4}{*}{$30 \%$ over-dosage } & 1 & 93 & 15 & 44 \\
\hline & & 2 & 89 & 9 & 33 \\
\hline & & 3 & 88 & 6 & 25 \\
\hline & & 4 & 90 & 5 & 24 \\
\hline \multirow{4}{*}{$\begin{array}{l}\mathrm{NO}_{\mathrm{x}^{-}} \\
\text {based }\end{array}$} & \multirow[t]{4}{*}{$30 \%$ dilution } & 1 & 80 & 4 & 17 \\
\hline & & 2 & 77 & 3 & 16 \\
\hline & & 3 & 77 & 3 & 20 \\
\hline & & 4 & 80 & 3 & 24 \\
\hline
\end{tabular}

metric feedforward urea injection approaches its expected value of $1 / 0.7=1.42$ after four ESC. The fluctuating post-SCR NO emissions are caused by the pulsating urea injection. The pulsations seem to lead to lower $\mathrm{NO}_{\mathrm{x}}$ conversion than would have resulted from continuous urea injection. In comparison with the $\mathrm{NH}_{3}$-based strategy, the $\mathrm{NO}_{\mathrm{x}}$-based strategy achieves roughly $10 \%$ less $\mathrm{NO}_{\mathrm{x}}$ conversion for the urea dilution case.

During tests, maximally four consecutive cycles are run. From these results, it is difficult to draw conclusions on convergence. A simulation study illustrated that both nonlinear 


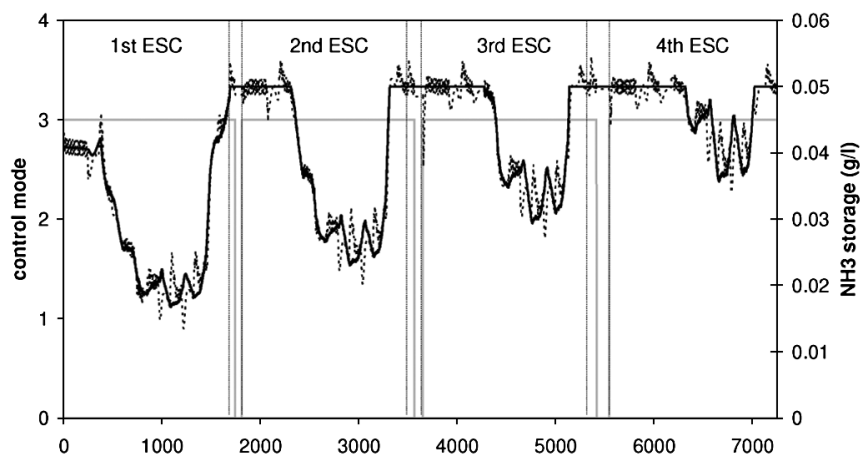

control mode $\cdots \cdots$ on-line $\mathrm{NH} 3$ storage estimate —- reference $\mathrm{NH} 3$ storage

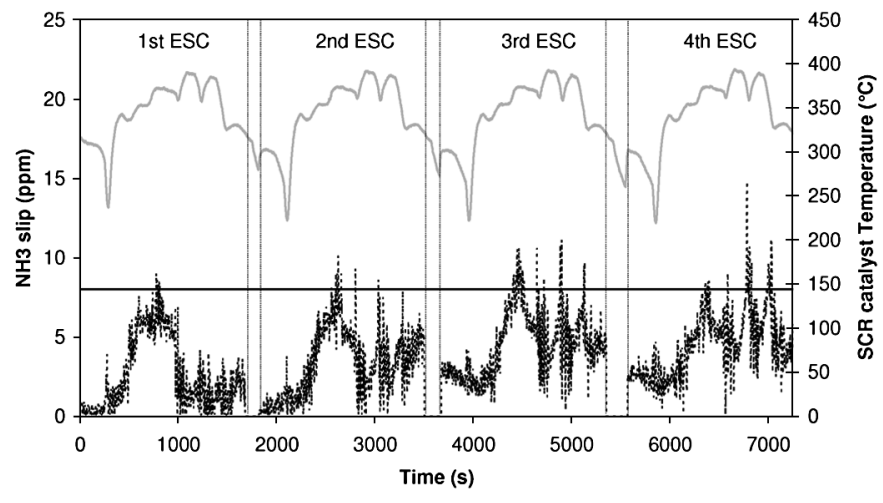

NH3 slip —- reference $\mathrm{NH} 3$ slip — T SCR cat

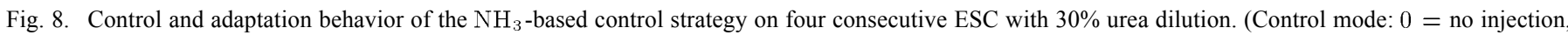
$2=\mathrm{NH}_{3}$ slip feedback control, $3=$ surface coverage control).

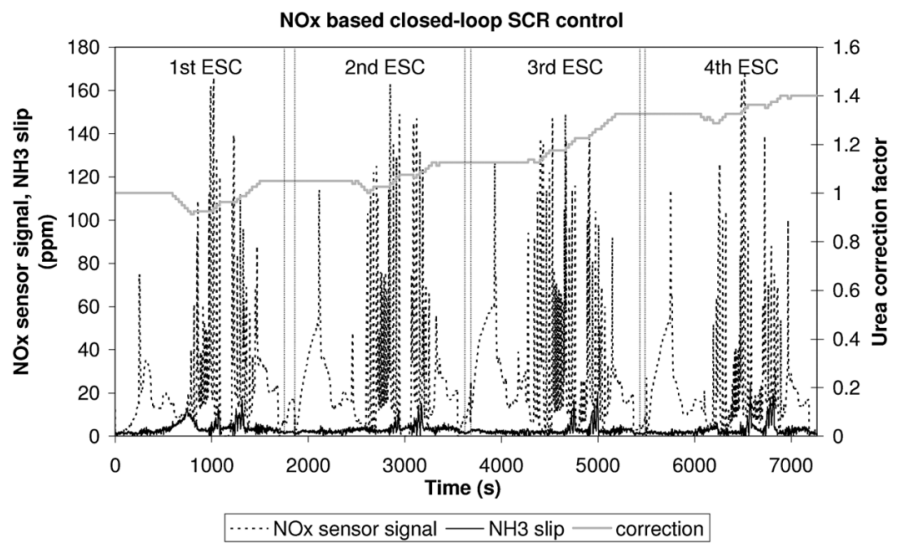

Fig. 9. Adaptation behavior of $\mathrm{NO}_{\mathrm{x}}$-based control on four consecutive ESC with $30 \%$ urea dilution.

strategies show convergence within eight cycles for the studied disturbances [21].

\section{CONCLUSION}

A new adaptive surface coverage and $\mathrm{NH}_{3}$ slip control strategy has been presented, which uses ammonia sensor information. This strategy deals with the $\mathrm{NH}_{3}$ slip constraint by adjusting the ammonia buffering in the SCR catalyst. In addition, it offers robustness against system deviations by ammonia feedback control.

The $\mathrm{NH}_{3}$ sensor-based control strategy was successfully implemented on the test setup, which comprised a 12-liter diesel engine equipped with a 34-liter Fe-Zeolite SCR system. A high fidelity, phenomenological SCR system model was fitted on engine dynamometer data and accurately describes the SCR system behavior. This real-time model is embedded in the controller and facilitates dependable ammonia surface coverage control.

The potential of the proposed strategy experimentally was validated for two cases: $30 \%$ urea under- and overdosage. The new strategy excels in avoiding $\mathrm{NH}_{3}$ slip while maintaining a high $\mathrm{NO}_{\mathrm{x}}$ conversion level. With targeted average and peak ammonia slips of 10 and $25 \mathrm{ppm}$, respectively, $\mathrm{NO}_{\mathrm{x}}$ conversion as high as $92 \%$ is achieved for both ESC and ETC, despite the large disturbances in urea dosage.
Comparison with a $\mathrm{NO}_{\mathrm{x}}$ sensor-based control strategy with cross-sensitivity compensation shows that the $\mathrm{NH}_{3}$ sensorbased strategy gives better performance and robustness for the studied cases. The $\mathrm{NO}_{\mathrm{x}}$ sensor-based strategy can adapt only in stationary conditions, while the proposed $\mathrm{NH}_{3}$ sensor-based strategy copes well with the European transient cycle as well.

Due to OBD requirements, engine platforms are likely to be equipped with a tailpipe $\mathrm{NO}_{\mathrm{x}}$ sensor. Current research focuses on the application of an SCR observer, using information from different combinations of $\mathrm{NO}_{\mathrm{x}}$ and $\mathrm{NH}_{3}$ sensors. The ultimate goal is an Integrated Emission Management Strategy that optimizes the synergy between engine and aftertreatment system. For instance, strategies for systems with close-coupled SCR catalysts [22], EGR/SCR balancing and different thermal management strategies are being examined to enhance low temperature performance of SCR systems.

\section{ACKNOWLEDGMENT}

The authors would like to thank Delphi, especially, D. Y. Wang and D. Cabush, for fruitful discussions and approval to publish the experimental data. Part of this research was done in the framework of the PREDUCE Research Program.

\section{REFERENCES}

[1] J. Patchett, R. Verbeek, K. Grimston, G. Rice, J. Calabrese, and M. van Genderen, "Control system for mobile $\mathrm{NO}_{\mathrm{x}}$ SCR applications," U.S. Patent 6581 374, Jun. 24, 2003.

[2] D. Seher, M. Reichelt, and S. Wickert, "Control strategy for $\mathrm{NO}_{\mathrm{x}}$ - Emission reduction with SCR," SAE, Warrendale, PA, Tech. Rep. 2003-01-3362, 2003.

[3] D. Wang, S. Yao, D. Racine, D. Cabush, and M. Shost, "Ammonia sensor for SCR $\mathrm{NO}_{x}$ reduction," presented at the DEER Conf., Detroit, MI, 2007. [Online]. Available: http://www1.eere.energy.gov/vehiclesandfuels/resources/proceedings/2007_deer_presentations.html

[4] C. Schär, C. Onder, M. Elsener, and H. Geering, "Model-based control of an SCR system for a mobile application," SAE, Warrendale, PA, Tech. Rep. 2004-05-0412, 2004.

[5] F. Willems, R. Cloudt, E. van den Eijnden, M. van Genderen, R. Verbeek, B. de Jager, W. Boomsma, and I. van den Heuvel, "Is closed-loop SCR control required to meet future emission targets?," SAE, Warrendale, PA, Tech. Rep. 2007-01-1574, 2007.

[6] R. Cloudt, E. van den Eijnden, and P. van der Heijden, "Meeting future emission legislation with advanced diesel SCR control systems," JSAE, Yokohama, Japan, Tech. Rep. 20095307, 2009.

[7] E. van den Eijnden, R. Cloudt, F. Willems, and P. van der Heijden, "Automated model fit tool for SCR control and OBD development," SAE, Warrendale, PA, Tech. Rep. 2009-01-1285, 2009. 
[8] R. Cloudt, J. Saenen, E. van den Eijnden, and C. Rojer, "Virtual exhaust line for model-based diesel aftertreatment development," SAE, Warrendale, PA, Tech. Rep. 2010-01-0888, 2010.

[9] M. Koebel, M. Elsener, and M. Kleemann, "Urea-SCR: A promising technique to reduce $\mathrm{NO}_{\mathrm{x}}$ emissions from automotive diesel engines," Catalyst Today, vol. 59, pp. 335-345, 2000.

[10] I. Nova, L. Lietti, E. Tronconi, and P. Forzatti, "Transient response method applied to the kinetic analysis of the $\mathrm{DeNO}_{\mathrm{x}}-\mathrm{SCR}$ reaction," Chem. Eng. Sci., vol. 56, no. 5, pp. 1229-1237, 2001.

[11] C. Schär, C. Onder, and H. Geering, "Control of an SCR catalytic converter system for mobile heavy-duty application," IEEE Trans. Control Syst. Technol., vol. 14, no. 4, pp. 641-653, Jul. 2006.

[12] M. Devarakonda, G. Parker, J. Johnson, V. Strots, and S. Santhanam, "Model-based estimation and control system development in a urea-SCR aftertreatment system," SAE, Warrendale, PA, Tech. Rep. 2008-01-1324, 2008.

[13] M. Krijnsen, "Advanced control of $\mathrm{NO}_{x}$ diesel emissions," Ph.D. dissertation, Chemical Eng., Delft Univ. Technol., Delft, The Netherlands, 2000.

[14] Q. Song and G. Zhu, "Model-based closed-loop control of urea SCR exhaust aftertreatment system for diesel engine," SAE, Warrendale, PA, Tech. Rep. 2002-01-0287, 2002.

[15] D. Upadhyay and M. van Nieuwstadt, "Exhaust gas aftertreatment systems," U.S. Patent 6933 900, Feb. 7, 2006.
[16] J. Chi and H. DaCosta, "Modeling and control of a urea-SCR aftertreatment system," SAE, Warrendale, PA, Tech. Rep. 2005-01-0966, 2005.

[17] D. Upadhyay and M. van Nieuwstadt, "Model based analysis and control design of a urea-SCR deNO ${ }_{\mathrm{x}}$ aftertreatment system," ASME $J$. Dyn. Syst., Meas., Control, vol. 128, pp. 737-741, 2006.

[18] Y. Murata, S. Tokui, S. Watanabe, Y. Daisho, H. Suzuki, and H. Ishii, "Improvement of $\mathrm{NO}_{\mathrm{x}}$ reduction rate of urea-SCR system by $\mathrm{NH}_{3}$ adsorption quantity control SAE, Warrendale, PA, Tech. Rep. 2008-012498, 2008.

[19] Y. Yasui, J. Iwamoto, and H. Ogihara, "Exhaust gas purifying apparatus en method for internal combustion engines and engine control unit," U.S. Patent 7204 081, Apr. 17, 2007.

[20] D. Wang, W. Symons, R. Farhat, C. Valdes, E. Briggs, K. Polikarpus, and J. Kupe, "Ammonia gas sensors," U.S. Patent 7074 319, Jul. 11, 2006.

[21] D. Wang, S. Yao, M. Shost, J. Yoo, D. Cabush, D. Racine, R. Cloudt, and F. Willems, "Ammonia sensor for closed-loop SCR control," SAE Int. J. Passenger Cars-Electron. Elect. Syst., vol. 1, no. 1, pp. 323-333, 2009.

[22] R. Cloudt, R. Baert, F. Willems, and M. Vergouwe, "Innovative SCRonly concept for heavy-duty Euro VI applications," Motortechnische Zeitschrift (MTZ), vol. 70, no. 9, pp. 58-63, 2009. 